\title{
A Survey of the Effect of Strategies, Technologies and Organizational Learning on Organization Innovation in it Organizations: Case Study of Information Technology Organization of Iran
}

\author{
Ali Reza Sayad Sarabestany ${ }^{* 1}$ \\ Heydar Amiran²

\begin{abstract}
${ }^{1}$ Master of Public Management, Center Tehran Branch, Islamic Azad University, Tehran, Iran 2 Ph.D. In Industrial Management, Department of Industrial Management, Faculty of Management Central Tehran Branch, Islamic Azad University, Tehran, Iran; *Corresponding Author
\end{abstract}

\author{
Doi:10.5901/mjss.2016.v7n2s2p154
}

\begin{abstract}
In the present competitive world, the organizations with high innovation capacity can respond to environmental challenges rapidly. The capabilities and innovation performance are affected by absorptive, shared and applied knowledge from organization. Entrepreneurial direction providing some motivations for organizations for learning and increase of social system of company and technology organization focusing mostly on taking new technologies for innovation of capabilities for organizational innovation are necessary. The present study aimed to evaluate the effect of strategies, technologies and organizational learning on organizational innovation in IT organizations of case study of IT organizations by structural equations model. The study population is all employees of IT organization in Iran as 400. 196 employees are selected by Cochran's formula by random sampling method. They answered technology orientation, entrepreneurial organization, organizational learning, application of knowledge management system and organizational innovation questionnaires. For data analysis, descriptive indices, confirmatory analysis and structural equations model were used by SPSS, SMARTPLS software. The results of structural equations model showed that impact coefficient of entrepreneurial orientation had positive and significant effect on using knowledge management and organizational learning. Impact coefficient of technological orientation had positive and significant effect on using knowledge management and organizational learning. Impact coefficient of using knowledge management system had positive and significant effect on organizational innovation. The impact coefficient of organizational learning had positive and significant effect on organizational innovation. Totally the findings emphasized on the role of technological orientation, entrepreneurial orientation, using knowledge management system and organizational learning in organizational innovation in the studied organization.
\end{abstract}

Keywords: Entrepreneurial orientation, Organizational innovation, Organizational learning, Technological orientation, Using knowledge management system.

\section{Introduction}

For survival and keeping competitive advantage, organizations are obliged to be creative and innovative (Niro Jokar, 2012). In such spaces, the organizations with high innovation capacity can respond to environmental challenges rapidly and use new productions and market opportunities better than non-innovative organizations (Jiménez-Jiménez, D., \& Sanz-Valle, 2010). The innovative performance and capabilities are affected by absorptive, shared and applied knowledge form organization and these innovation capabilities can lead to suitable innovation performance, high speed and good quality in innovation (Cohen, W. M., Levinthal, 1990). The great changes and challenges of the present world require that an organization with learning power is formed to be adaptable with rapid changes and respond to environmental drivers timely and by achieving knowledge and awareness as dynamic and extensive in improvement and organizational development, can continue their life. Organizational learning is one of the vital sources to achieve competitive advantage in strategic management (Lopez et al., 2005). In addition, competition on one hand and continuous changes on the other hand encounter the organizations with complex conditions as requiring the need to strategy and long-term plan. In designed strategy for organization, we can consider the introductions of this strategy (Rahimnia and Sadeghian, 2011). One of the preparations for strategic orientation is referring to the long-term condition of organization in competitive environment and allocation of priority of resources. Strategic orientation is directing the goals organization attempts to achieve (Lau, 2011). Entrepreneurial orientation provides some motivations for organizations for learning and increasing social system of company. Entrepreneurial orientation focusing on achieving 
external knowledge and developing attitude to change is effective on organizational learning (Zhou et al., 2005). Technological orientation is another key factor of development of organizational innovations as focusing mostly on acquiring new technologies for innovation of necessary capabilities for organizational innovation (Yu et al., 2013). Alos, it leads to the increase of ability of company and acquiring considerable technological foundations and using it in new products development (Gatignon H, Xuereb, 1997). Although other studies evaluated the relationship between Entrepreneurial orientation, technology, knowledge management and organizational learning on organizational innovation, their relationship was less considered in Iran. This study has an interactive view in organizational innovation and it shows how Entrepreneurial orientation, technology, knowledge management and organizational learning as formed in recent views act as coherent set in organization responsible for management, support, organizing, supervision and guiding IT sector. The present study aimed to investigate the relationship between strategic orientation (Entrepreneurial orientation and technology), knowledge management, organizational learning and organizational innovation. In this study, besides the direct effect of using knowledge management system and organizational learning on organizational innovation , indirect effect of Entrepreneurial orientation and technological orientation via knowledge management system and organizational learning on organizational innovation can be investigated.

\section{Theoretical Basics}

According to Druker, "innovation or death"( Ortt,. vander). Innovation is a continuous and planning process increasing the power and competitive advantage of company via reduction of costs and reduction of price of products, better quality and high efficiency and effectiveness of goods and services and it increases income and fame of organization. Organizational innovation is referred to the development or acceptance of an idea or behavior in business operation as new for the entire organization. It is creating value of new technology or new administrative activities based on new products or processes (Jiménez-Jiménez, 2008). There are various types of innovations. Innovation in goods and services, innovation in strategy and structure, innovation in culture and technology. Radical innovation, gradual innovation and common innovation are other types of innovation (Mobini Dehkordi, 2008, 11). Knowledge management is conscious process of creating knowledge, validation, distribution and application. In this definition, the main components of knowledge management include information, people and system (Zarabadipour and Zargarpour, 2007). Many of theorists of management discussed about knowledge management evolution and we can refer to Peter Drueker, Powel Strawsman, and Peter Senge from US. Cohen, W. M., Levinthal (1990) stated that innovation performance and capabilities are affected mostly by absorptive, shared and applied knowledge from organization and these innovative capabilities can lead to good performance of innovation, high speed and good quality in innovation. Organizational learning is increasing ability of organization for effective and efficient works. Learning in organization is occurred when the managers and key people of organization are aware of phenomena in organization and second, this recognition is manifested beside their performance and organization complex (Senge, 1990). Friedman, V. J., Lipshitz, R., \& Popper (2005) believe that to establish learning in organization, some duties and processes should be defined in roles that organizational members systematically collect, analyze, store and use the information of their performance and other members of organization as driving force of learning organization. Entrepreneurship means using opportunities, with high efforts with accepting financial, mental and social risk (Hisrich, R. D. \& peters, 2002). Entrepreneurial orientation is vital widely for each type and size of organization (Chrisman, J.J., Chua, J.H., and Sharma, 2003). John Thompson believes that Entrepreneurial orientation is a necessary requirement for all organizations (state, private, voluntary, etc.) with any size (Big, average and small)(Thompson, 1999). Technology orientation is a key factor for development of organizational innovations. Technological orientation focuses mostly on acquiring new technologies to innovate necessary capabilities and applications for organizational innovation (Yu et al., 2013). Tanriverdi (2005) states that technology orientation leads to understanding needs of knowledge in business units, facilitation of identification of resources and motivations of business units for organizational knowledge of managers. Venkatraman (1989) states that technological orientation besides creativity and technological changes leads to searching the root of problems and production of the best solutions for them.

\section{Review of Literature}

Safarzade, Tadayon and Hormohammadi (2012) conducted a study to evaluate the effect of knowledge management strategies on innovation and organizational performance. The results showed that knowledge management had positive effect on innovation and organizational performance. In addition, organizational innovation had positive direct effect on organizational performance. In the study done by Rahimnia and Sadeghian (2011) on export companies in Mashad city, it 
was found that strategic orientation had positive effect on success of export and future success of export. Amani (2008) evaluated the relationship between knowledge management and organizational learning with creativity and organizational innovation in managers of schools in districts 4, 9 of city. The results showed that knowledge management and its dimensions and organizational learning and its dimensions had positive and significant relationship with creativity and organizational innovation. In the study of Yu et al.,(2013) to evaluate the relationship between strategies, technologies, organizational learning and organizational innovation, it was found that entrepreneurial orientation and technology had positive and significant effect on using knowledge management and organizational learning. Organizational learning and knowledge management had positive and significant effect on organizational innovation. In the study done by Ferraresi et al., (2012) to evaluate the relationship between knowledge management variables, strategic orientation, organizational innovation and organizational performance, it was found that knowledge management had direct effect on strategic orientation but the relationship between other variables was not significant. In the study done by Theodosiou et al., (2012), the relationship between strategic orientation and company performance was evaluated. The results showed that there was a significant correlation between these two variables. Zheng et al., (2010) found that knowledge acquiring and its sharing was effective on innovation and development of product and improvement of organizational performance. In other words, integration of organizational knowledge can lead to development of product, reduction of disadvantages and increase of organizational efficiency. Hind (2008) evaluated the relationship between knowledge management and creativity and innovation of managers of high education centers. The results of study showed that knowledge management variable had positive, direct and significant effects on creativity and innovation. Also, creativity variable had positive and significant effect on innovation variable.

\section{Conceptual Model of Study}

The variables of study and their relationship are shown in conceptual model in Figure 1.

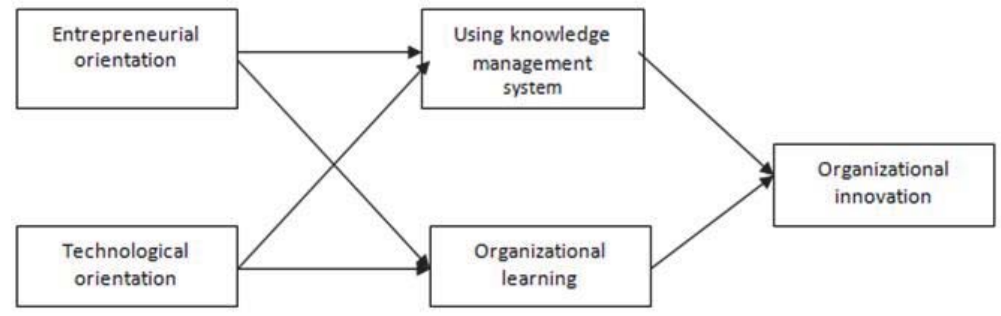

Figure 1 - Conceptual model of study (Source: Yu et al ., 2013)

As shown in conceptual model of Figure 1, the following hypotheses are used:

1- Entrepreneurial orientation has positive effect on knowledge management system.

2- Entrepreneurial orientation has positive effect on organizational learning

3- Technological orientation has positive effect on knowledge management system.

4- Technological orientation has positive effect on organizational learning

5- Using knowledge management system has positive effect on organizational innovation.

6- Organizational learning has positive effect on organizational innovation.

\section{Study Method}

This study is applied in terms of purpose and nature and is descriptive (non-experimental) in terms of method and study is correlation and structural equations model.

The study population is all employees of IT organization of Iran as 400. Based on study population, sample size is 196 based on Cochran's formula. The data collection method is library and fieldwork study.

In this study, to evaluate reliability, Cronbach's alpha coefficient and Composite reliability are used. To evaluate validity of measure, besides content validity, confirmatory factor analysis is applied.

Variables of study are entrepreneurial orientation, technological orientation as independent variable's, knowledge management and organizational learning as mediating variable and organizational innovation as dependent variable . To 
measure all these variables, Yu et al., (2013) scale is applied including 4 questions for innovation, 3 questions for entrepreneurial orientation, 4 questions for technological orientation, 12 questions for organizational learning, 4 questions for measuring application of knowledge management system. For analysis of data of study, descriptive tests as percentage, mean and standard deviation and inferential tests as Pearson correlation tests, structural equations by partial least squares (PLS) are used by SPSS, SMARTPLS software.

\section{Findings}

\subsection{Descriptive statistics}

Findings showed that $52 \%$ of respondents were men and $48 \%$ women. The people with BA (47.96\%) had the highest statistical sample. The people aged $20-30$ years old were $39.76 \%, 31-40$ years $47.46 \%$ and above 41 years $12.76 \%$ of study sample. People with work experience 1 to 5 years had the highest study sample (45.41\%).

\section{Inferential Statistics}

\subsection{The evaluation of reliability of measures}

To investigate reliability of constructs, Fornell and Larcker (1981) proposed three criteria as 1- Reliability of each of items, 2- Composite reliability of each of constructs, 3- Average Variance Extracted (AVE). Regarding reliability of items, factor load 0.5 and above each item in confirmatory factor analysis showed good construct. Also, factor load of items should be significant at least at level 0.01(Gefen, D. \& Straub, 2005). To evaluate composite reliability of each of constructs, Dillon Goldstein coefficient (c $\rho$ ) is applied (Manuel et al., 2009). Acceptable values of c $\rho$ should be 0.7 or above (Fornell and Larcker, 1981). The third indicator is the evaluation of reliability, Average Variance Extracted (Fornell and Larcker, 1981). Fornell and Larcker recommend AVE values 0.5 and above and this means that the required construct determines about $50 \%$ or above of variance of indicators. Table 1 depicts factor loads, $c \rho$, AVE and alpha coefficient of entrepreneurial orientation as example. The values show good reliability of constructs.

Table 1 - Reliability indices of entrepreneurial orientation

\begin{tabular}{|c|c|c|}
\hline Value T & Factor load & Item \\
\hline 20.961 & 0.75 & Question 1 \\
\hline 30.513 & 0.82 & Question 2 \\
\hline 22.888 & 0.76 & Question 3 \\
\hline 0.82 & & cP \\
\hline 0.61 & & AVE \\
\hline 0.70 & & $a$ \\
\hline
\end{tabular}

\section{Evaluation of Validity of Measures}

To evaluate the validity or divergent validity of constructs, Chin (1998) recommends two criteria as 1- The items of one construct should have high factor load on construct. Second criterion as squared AVE should be more than correlation of the construct with other constructs. This shows that the correlation of the construct with its indicators is higher than its correaiton with other constructs. Tables 2, 3 show sectional load of items on constructs of study.

Table 2 - Crossed factor loads to evaluate validity of measures in sub-hypotheses of study

\begin{tabular}{|l|c|c|c|c|c|}
\hline Variable & $\begin{array}{c}\text { Entrepreneurial } \\
\text { orientation }\end{array}$ & $\begin{array}{c}\text { Technological } \\
\text { orientation }\end{array}$ & $\begin{array}{c}\text { Knowledge } \\
\text { management }\end{array}$ & $\begin{array}{c}\text { Organizational } \\
\text { learning }\end{array}$ & $\begin{array}{c}\text { Organizational } \\
\text { innovation }\end{array}$ \\
\hline \multirow{3}{*}{ Organizational innovation } & 0.31 & 0.40 & 0.58 & 0.49 & 0.83 \\
\cline { 2 - 6 } & 0.31 & 0.35 & 0.61 & 0.57 & 0.88 \\
\cline { 2 - 6 } & 0.32 & 0.37 & 0.68 & 0.56 & 0.88 \\
\cline { 2 - 6 } & 0.37 & 0.44 & 0.44 & 0.43 & 0.55 \\
\hline Technological orientation & 0.24 & 0.85 & 0.43 & 0.45 & 0.31 \\
\hline
\end{tabular}




\begin{tabular}{|l|c|c|c|c|c|}
\hline \multirow{5}{*}{} & 0.18 & 0.83 & 0.49 & 0.42 & 0.39 \\
\cline { 2 - 6 } & 0.34 & 0.83 & 0.48 & 0.49 & 0.45 \\
\cline { 2 - 6 } & 0.39 & 0.87 & 0.60 & 0.53 & 0.46 \\
\hline Entrepreneurial orientation & 0.75 & 0.17 & 0.39 & 0.36 & 0.27 \\
\cline { 2 - 6 } & 0.82 & 0.32 & 0.39 & 0.44 & 0.31 \\
\cline { 2 - 6 } & 0.76 & 0.31 & 0.37 & 0.34 & 0.36 \\
\hline Knowledge management & 0.38 & 0.34 & 0.77 & 0.49 & 0.65 \\
\cline { 2 - 6 } & 0.35 & 0.43 & 0.78 & 0.65 & 0.61 \\
\cline { 2 - 6 } & 0.37 & 0.45 & 0.76 & 0.68 & 0.57 \\
\cline { 2 - 6 } & 0.40 & 0.59 & 0.77 & 0.59 & 0.48 \\
\cline { 2 - 6 } & 0.29 & 0.41 & 0.61 & 0.79 & 0.59 \\
\cline { 2 - 6 } & 0.22 & 0.40 & 0.61 & 0.67 & 0.48 \\
\cline { 2 - 6 } & 0.46 & 0.47 & 0.48 & 0.69 & 0.38 \\
\hline
\end{tabular}

As shown in the above Tables, all items had highest factor load on their construct and minimum distance between factor load of their construct more than 0.1 and it showed study constructs had good divergent validity. Table 3 reports the results of evaluation of second criterion. As shown in Table 3, squared mean of extracted variance of all variables of study was higher than their correlation with other variables. Thus, the second criterion of evaluation of divergent validity is satisfied. In addition, correlation of all variables was positive and significant.

Table 3 - Correlation matrix and squared mean extracted variance of each of study variables

\begin{tabular}{|c|c|c|c|c|l|c|}
\hline 5 & 4 & 3 & 2 & 1 & Variable & No. \\
\hline & & & & 0.78 & Entrepreneurial orientation & 1 \\
\hline & & & 0.85 & ${ }^{* *} 0.33$ & Technological orientation & 2 \\
\hline & & - & ${ }^{* *} 0.57$ & ${ }^{* *} 0.49$ & Using knowledge management & 3 \\
\hline & 0.68 & ${ }^{* *} 0.45$ & ${ }^{* *} 0.52$ & ${ }^{* *} 0.52$ & Organizational learning & 4 \\
\hline 0.79 & ${ }^{* *} 0.52$ & ${ }^{* *} 0.74$ & ${ }^{* *} 0.48$ & ${ }^{* *} 0.41$ & Organizational innovation & 5 \\
\hline \multicolumn{7}{|l|}{ Note: Values on diagonal of correlation matrix of square mean of extracted variance. } \\
\hline
\end{tabular}

\section{Structural Model Test}

\subsection{Structural model for main hypothesis}

To predict organizational innovation, proposed conceptual model is investigated by structural equations modeling and partial least squares is used to estimate the model. Structural model test and study hypotheses in PLS method are possible via evaluation of path coefficients (factor loads) and R2 values (Seyed Abbaszade et al., 2012). Also, bootstrap methods (300 sub-samples) are used to compute T statistics values to determine significance of path coefficients. The path coefficients are used to determine the share of each of predictive variables in explanation of criterion variance and R2 values show explained variance of criterion variable by predictive variables. In addition, Q2 Stone - Giesser coefficient is used to evaluate predictively of dependent variables from independent variables. Positive values of this coefficient showed predictability. Figure 2 shows tested model of the relationship between study variables. Entrepreneurial orientation and strategy orientation have positive and significant effect on using knowledge management system and organizational learning. Using knowledge management system and organizational learning have positive and significant effect on organizational innovation. The values in the circle are explained variance of study variables. 


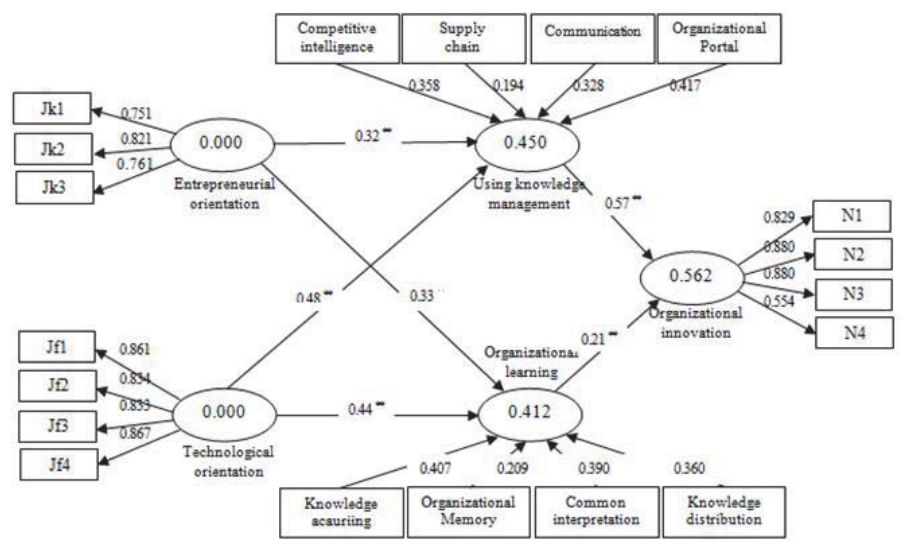

Figure 2 - Tested model of study

T-coefficients above \pm 1.96 to \pm 2.58 are significant at level 0.05 and t-coefficients above \pm 2.58 are significant at the level 0.01 . As shown in Figure 3, t-coefficients of all paths are above 2.58 and it shows that all paths are significant at the level 0.01. The direction of t-coefficients in all paths is positive and it shows positive and significant effect.

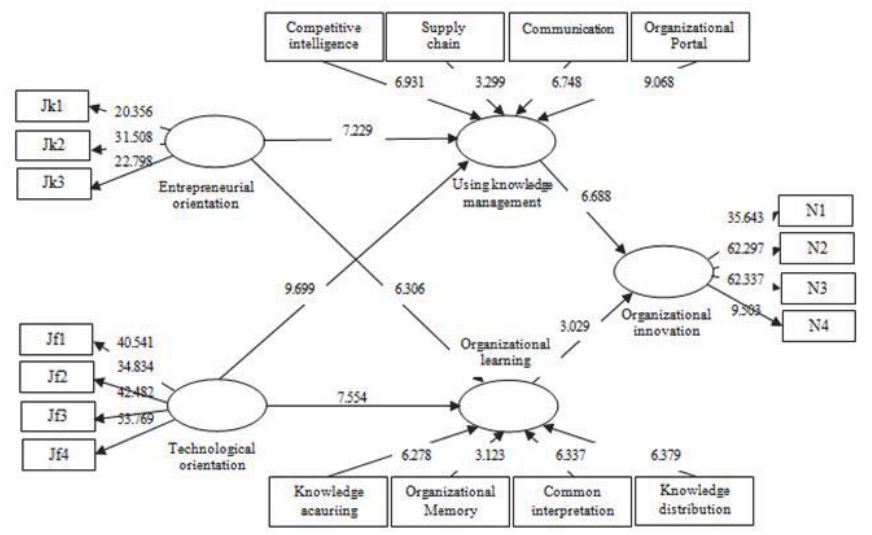

Figure 3 - Tested model t-coefficient

In Table 4, the estimation of direct, indirect coefficients and total variables of study is reported. As shown in Table 4, entrepreneurial orientation and strategy orientation had positive and significant effect on using knowledge management system and organizational learning. Using knowledge management system and organizational learning has positive and significant effect on organizational innovation. In addition, entrepreneurial orientation and strategy orientation via organizational learning and using knowledge management system had indirect positive and significant effect on organizational innovation. As shown in Table 4, $56 \%$ of variance of organizational innovation, $41 \%$ of organizational learning variance and $45 \%$ of variance of using knowledge management system were explained by model of study.

Table 4 - The direct, indirect, total coefficients and explained variance

\begin{tabular}{|c|c|c|c|l|}
\hline Explained variance & Total effect & Indirect effect & Direct effects & Variables \\
\hline 0.56 & ${ }^{* *} 0.21$ & - & ${ }^{* *} 0.21$ & $\begin{array}{l}\text { On organizational innovation from: } \\
\text { Organizational learning }\end{array}$ \\
\hline
\end{tabular}




\begin{tabular}{|c|c|c|c|c|}
\hline & $\begin{array}{l}{ }^{* *} 0.57 \\
{ }^{* *} 0.37 \\
{ }^{* *} 0.26\end{array}$ & $\begin{array}{l}{ }^{-} \\
{ }^{* *} 0.37 \\
{ }^{* *} 0.26\end{array}$ & 0.57 & $\begin{array}{l}\text { Using knowledge management Technological orientation } \\
\text { Entrepreneurial orientation }\end{array}$ \\
\hline 0.41 & ${ }^{* *} 0.44$ & - & ${ }^{* *} 0.44$ & $\begin{array}{l}\text { On organizational learning from: } \\
\text { Technological orientation } \\
\text { Entrepreneurial orientation }\end{array}$ \\
\hline 0.45 & $\begin{array}{l}{ }^{* *} 0.48 \\
{ }^{* *} 0.32\end{array}$ & - & $\begin{array}{l}{ }^{* *} 0.48 \\
{ }^{* *} 0.32\end{array}$ & $\begin{array}{l}\text { On using knowledge management system from: } \\
\text { Technological orientation } \\
\text { Entrepreneurial orientation }\end{array}$ \\
\hline
\end{tabular}

Table 5 shows the explained variance, Communality and redundancy of study variances. As shown in Table, all values of Communality and redundancy are positive and it shows good quality of present study model.

Table 5 - Explained variance of Communality and redundancy of variables

\begin{tabular}{|c|c|c|l|}
\hline CV- Communality & Q $^{2}$ CV-Redundancy & Explained variance & Study variables \\
\hline 0.636 & 0.353 & $56 \%$ & Organizational innovation \\
\hline 0.515 & 0.158 & $41 \%$ & Organizational learning \\
\hline 0.595 & 0.201 & $45 \%$ & Using knowledge management \\
\hline 0.717 & 0.717 & - & Technological orientation \\
\hline 0.606 & 0.606 & - & Entrepreneurial orientation \\
\hline
\end{tabular}

\subsection{Structural model fit}

Finally, to show validity of study findings, fit indices of structural equations by partial least squares is used.

There are some methods to evaluate the validity of model in PLS. These methods are called Cross-validation including the evaluation of validity of CV- Communality and CV-Redundancy (Tenen Haus et al., 2005). As shown in Table 5, positive value of Communality and redundancy for all variables show good quality of measurement model. In addition to the above indices, general fit index of model in PLS is Goodness Of Fit (GOF) and it is used to evaluate validity or quality of PLS model as general. This index acts like fit indices of Lisrel model and is ranging 0 to 1 and values close to 1 indicate good quality of model. In the present study, for the tested model, absolute fit GOF was 0.54 and the value for this fit index indicated good fit of tested model.

\subsection{Study hypotheses test}

First hypothesis: Entrepreneurial orientation had positive effect on using knowledge management system.

Findings of Table 4 showed that impact coefficient of entrepreneurial orientation had positive and significant effect on using knowledge management system $(\beta=0.32)$ at level $P<0.01$. Thus, first hypothesis of study is supported and entrepreneurial orientation has positive and significant effect on using knowledge management. This finding is consistent with the results of study of Yu et al., (2013). This finding shows that when the organization predicts business trends by necessary indices as company strategy, strategic resources, relationship with customers and value network, business trends in organization are followed and rapid reaction is shown and it is attempted to detect opportunities to develop business and the probability of using knowledge management in organizations is increased.

Second hypothesis: Entrepreneurial orientation has positive effect on organizational learning.

Findings of Table 4 show that impact coefficient of Entrepreneurial orientation on organizational learning $(\beta=0.33)$ is positive and significant at the level $P<0.01$. Thus, second hypothesis is supported and Entrepreneurial orientation has positive and significant effect on organizational learning. This finding is consistent with the results of study of Yu et al. , (2013) and Zhou et al., (2005). Zhou et al., (2005) in this finding states that Entrepreneurial orientation provides some motivations for organizations for learning and increase of social system (interactions, communication among employees) of company. In addition, Entrepreneurial orientation via focusing on external knowledge acquiring and development of attitude to change is effective on organizational learning. Thus, Entrepreneurial strategic orientation causes that the organization has open approach (is not resistant against change and it is prepared to be adaptable with environmental changes) to environment responses as an opportunity and this leads to resources commitment to detect opportunities, continuous organizational learning. 
Third hypothesis: Technological orientation has positive effect on using knowledge management system.

The findings of Table 4 show that impact coefficient of technology orientation on using knowledge management system $(\beta=0.48)$ was positive and significant at level $P<0.01$. Thus, third hypothesis of study is supported and technological orientation has positive and significant effect on using knowledge management system. This finding is consistent with the results of study of Yu et al., (2013). This finding shows that when the company focuses on using information systems, using advanced technologies and technological innovations, the probability of using knowledge management system in organizations. Thus, technological orientation can make knowledge management processes and systems as available to achieve knowledge and this can lead to value-added creation for organization.

Fourth hypothesis: Technological orientation has positive effect on organizational learning.

Findings of Table 4 show that impact coefficient of technological orientation had significant and positive effect on organizational learning $(\beta=0.33)$ at level $P<0.01$. Thus, fourth hypothesis of study is supported and technological orientation has positive and significant effect on organizational learning.It is consistent with the studies of $Y u$ et al ., (2013). This finding shows that technological orientation via achieving new technologies and using them can increase knowledge and ability of company and achieving technologies foundations and using it in organization and it is effective on organizational learning.

Fifth hypothesis: Using knowledge management system has positive effect on organizational innovation.

The findings of Table 4 show that impact coefficient of using knowledge management system on organizational innovation $(\beta=0.57)$ is positive and significant at the level $P<0.01$. Thus, fifth hypothesis is supported and using knowledge management system has positive and significant effect on organizational innovation. This finding is consistent with the results of study of Liao, S., \& Wu (2010) and Yu et al., (2013). This finding shows that when there is innovation in organization, knowledge management facilitates knowledge integration between work units and groups and it also facilitates knowledge among the groups and knowledge is integrated rapidly and effectively. In addition, knowledge management provides required tools, processes and infrastructures for knowledge sharing among the employees and it is effective on organizational innovation. Thus, we can say, without knowledge, there is no innovation. In other words, innovation is not created in vacuum and it needs conditions, grounds.

Sixth hypothesis: Organizational learning has positive effect on organizational innovation.

The findings of Table 4 show that impact coefficient of organizational learning has positive and significant effect on organizational innovation $(\beta=0.21)$ at level $P<0.01$. Thus, sixth hypothesis of study is supported and organizational learning has positive and significant effect on organizational innovation. This finding is consistent with the results of study of Yu et al., (2013). Regarding this finding, we can say increase of organizational learning via achieving new knowledge, acquiring skills, necessary capacities for competitive advantage, acquiring new knowledge outside organization, development of knowledge and sharing them enables the organization to perceive the needs of customers and competitive conditions better and increase organizational innovation along the development of new products and they can achieve competitive advantages and improve organizational performance. Organizational learning is the process of achieving and improvement of new knowledge and capacities. This process can improve organizational activities. Improvement of knowledge helps the facilitation of efficiency, productivity and innovation and effectivness. The good sharing and productivity of knowledge and its correct transfer provides an opportunity for the members of organization to start learning and employees are motivated to create new knowledge and apply new knowledge for organizational innovation. At the past, the organizations were in stable environment and prediction of future events was impossible as managers can manage and plan under reliable conditions. Gradually, the changes of science and technology, economy, culture and politics affect the organizations rapidly. Thus, organizational leaders found that they should view learning as valuable phenomenon and develop an organization for success in creating better future as learning continuously and they be successful in organizational innovation for their survival against the changes.

\section{Discussion and Conclusion}

Totally, the results showed that impact coefficient of entrepreneurial orientation had positive and significant effect on using knowledge management system $(\beta=0.32)$ and organizational learning $(\beta=0.33)$. Impact coefficient of technological orientation had positive and significant effect on using knowledge management system $(\beta=0.48)$ and organizational learning $(\beta=0.33)$. The impact coefficient of using knowledge management had positive and significant effect on organizational innovation ( $\beta=0.57)$. The impact coefficient of organizational learning on organization innovation $(\beta=0.21)$ was positive and significant. In addition, entrepreneurial orientation and technological orientation via using knowledge management system and organizational learning had indirect, positive and significant effect on organizational innovation. Regarding the explained variance of study variables, $56 \%$ of organizational innovation variance was explained by present 
study model. Thus, the results of present study emphasized the role of entrepreneurial orientation, technology, using knowledge management system and organizational learning in organizational innovation. In addition, based on the finding, we can say entrepreneurial and technological orientation indirectly was effective on organizational innovation via using knowledge management system and organizational learning.

\section{Study Recommendations}

a. It is proposed that IT organization in Iran by emphasis on prediction of business and rapid reaction to new opportunities, encourage the employees to use knowledge management systems in organization. The role of managers is of great importance in this regard.

b. The managers of IT organization in Iran via entrepreneurial orientation or the efforts to detect opportunities to develop business encourage the employees to achieve external knowledge and develop attitude to changes and increase organizational learning.

c. IT organization in Iran by emphasis on using information systems in decision making, outputs of information systems and using technologies can support the planning, use knowledge management system in organization as technology orientation increases the general perception of the need to knowledge, identification of knowledge resources and motivation to use organizational knowledge.

d. IT organization in Iran by encouraging employees to use new technologies affects curiosity and inclination to increase knowledge and learning of employees. Technological orientation besides creativity and changes of technology can lead to searching the problems and generation of the best solutions and increase of knowledge and organizational learning.

e. Leaders should have some abilities to facilitate the fulfillment of using knowledge management system. These skills include directing organizational change process, creating importance of knowledge sharing among employees, keeping their morale and creating norms encouraging knowledge sharing. Like all change and organizational improvement plans, support and commitment of top management of organization to knowledge management project is vital.

f. IT organization applies competitors, customers, suppliers and other partners to achieve new knowledge and organizational innovation.

g. IT organization in Iran by holding educational courses of managers, can be aware of important outcomes of technological and entrepreneurial orientation and teach them how we can use strategic orientations to increase organizational learning and knowledge and organizational innovation.

\section{References}

Ani, M. (2008). The evaluation of the relationship between knowledge management and organizational learning with organizational creativity and innovation in managers of schools of districts 4,9 of Tehran. MA thesis of educational management of Shahid Beheshti University.

Rahimnia, F., Sadeghian, H. (2011). Strategic orientation and success of export companies. Researches of organizational resources management. 1(1): 115-136.

Zahedi, Sh., Najari, R. (2008). Productivity of human resources and knowledge management.

Zarabadipour, S., Zargarpour, H. (2007). The evaluation of delays of a national project by knowledge management. The articles of the first national conference on knowledge management.

Mirmohammad, A., Amanisari Beglou, J., Khezri, A., Pashoy, Q. (2012). An introduction to structural equations modeling by PLS method and its application in behavioral sciences. Publisher: Orumie University publications.

Safarzade, H., Tadayon, A., Hormohammadi, M. (2012). The investigation of the effect of strategies of knowledge management on innovation and organizational performance (case study of health centers of north of Fars). Scientific-Research journal of health of Yazd. 11(1): 76-86.

Mobini Dehkordi, A. (2008). New approach to formation of national space of innovation, management and human resources in oil industry. 2: 2.

Nayer, N., Jokar, A. (2012). The relationship between knowledge management and creativity among librarians of academic libraries of Shiraz city. Health information management. 9(2): 224-232.

Chin, W. W. (1998). The partial least squares approach to structural equation modelling. In G. A. Marcoulides (Ed.), Modern methods for business research. Mahwah, NJ: Lawrence Erlbaum Associates, Inc. 295-336.

Chrisman, J.J., Chua, J.H., Litz, R. (2003). A unified systems perspective of family firm performance: An extension and integration. Journal of Business Venturing, 18: 467-472.

Cohen, W. M., Levinthal, D. A. (1990). Absorptive capacity: A new perspective on. 
Ferraresi, A.A., Quandt, C.O., Dos Santos, S.A., Frega, J.R. (2012). Knowledge management and strategic orientation: leveraging innovativeness and performance. Journal of Knowledge Management, 16(5): 688-71.

Fornell, C., Larcker, D.F. (1981). Evaluating structural equations models with unobservable variables and measurement error. Journal of Marketing Research, 18(1): 39-50.

Friedman, V. J., Lipshitz, R., Popper, M. (2005). The mystification of organizational learning. Journal of Management Inquiry, 14(1): 1930.

Gatignon, H., Xuereb, J-M. (1997). Strategic orientation of the firm and new product performance. Journal of Marketing Research, 34: 77-90.

Gefen, D., Straub, D.W. (2005). A practical guide to factorial validity using PLS-Graph: Tutorial and annotated example, Communications of the AIS, 16 (5): 91-109.

Hind, B. (2008). Introduction to Knowledge Management for Creativity and Innovation Minitrack. Journal of Knowledge Management , 12(78):121-149.

Hisrich, R. D., Peters, M. (2002), Entrepreneurship, New York: Mc-Graw Hil.

Jiménez-Jiménez, D., Sanz-Valle, R. (2010). Innovation, organizational learning, and performance. Journal of Business Research, In Press, Corrected Proof.

Jimenez-Jimenez, D. et al. (2008). Fostering Innovation: The role of market orientation and organizational learning. European Journal of Innovation Management, 11(3): 389-412.

Lau, C-M. (2011). Team and organizational resources, strategic orientations, and firm performance in a transitional economy. Journal of Business Research, 64: 1344-1351.

Learning, innovation. Admin. Sci. Quart. 35(1) 128-152.

Liao, S., Wu, C. (2010). System perspective of knowledge management, organizational learning, and organizational innovation. Expert Syst. Appl., 37(2): 1096-1103.

Lopez, S. P., Peón, J. M. M., Ordás, C. J. V. (2005). Organizational learning as a determining factor in business performance. Learning Organization, The, 12(3): 227-245

Ortt, R., Duin, R., Patrich, A. (2008). The evolution of innovation management towards contextual innovation. European Journal of Innovation Management, 11(4): 522-538.

Senge, P. (1990), "The fifth discipline: The art and practice of learning organization", New York, Doubleday.

Tanriverdi, H. (2005). Information technology relatedness, knowledge management capability, and performance of multibusiness firms. MIS quarterly, 311-334.

Tenenhaus, M., Vinzi, V. E., Chatelin, Y.-M., Lauro, C. (2005). PLS path modeling. Computational Statistics and Data Analysis, 48(1):159-205

Theodosiou, M., Kehagias, J., Katsikea, E. (2012). Strategic orientations, marketing capabilities and firm performance: An empirical investigation in the context of frontline managers in service organizations. Industrial Marketing Management, 41: 1058-1070.

Thompson, J. L. (1999). A strategic perspective of entrepreneurship. International Journal of Entrepreneurial Behavior \& Research, 5(6): 279-296.

Venkatraman, N. (1989). Strategic orientation of business enterprises: the construct, dimensionality, and measurement. Management science, 35(8): 942-962.

Yu, Y., Dong, X. Y., Shen, K. N., Khalifa, M., Hao, J. X. (2013). Strategies, technologies, and organizational learning for developing organizational innovativeness in emerging economies. Journal of Business Research, 66(12): 2507-2514.

Zheng, W., Yang, B., McLean, G. N. (2010). Linking organizational culture, structure, strategy, and organizational effectiveness: Mediating role of knowledge management. Journal of Business Research, 63(7): 763-771.

Zhou, K.Z., Gao, G.Y., Yang, Z., Zhou, N. (2005). Developing strategic orientation in china: Antecedents and consequences of market and innovation orientations. Journal of Business Research, 58: 1049-1058. 